JELTL (Journal of English Language Teaching and Linguistics) e-ISSN: 2502-6062, p-ISSN: 2503-1848

2019, Vol. 4(2)

www.jeltl.org

\title{
YouTube as a Learning Media to Improve the Student's Speaking Ability in 21st Century
}

\author{
Yuli Nurmala Sari \\ Yogyakarta State University, Indonesia \\ e-mail: ulinurma22@yahoo.com \\ Margana \\ Yogyakarta State University, Indonesia \\ e-mail:margana@uny.ac.id
}

\begin{abstract}
The development of students' skills, especially in speaking, is considered important to get more attention because speaking skill is included as one of the productive skills that requires a lot of practice rather than only learning the theory. In mastering speaking skill, it is regarded necessary to not only understand what others are talking about but also to respond and communicate effectively with others. Moreover, in this era, the students are not only expected being a communicative person but also the students are required to be more creative, having a good critical thinking and can collaborate to other people. Thus, a maximum use of instructional media, especially YouTube, is considered necessary in enhancing the development of students' speaking skill as a crucial capability to be possessed in the $21^{\text {st }}$ century. The aim of this study is mainly to describe YouTube's maximum use in terms of practice as well as disclose the benefits of using YouTube as a learning media.
\end{abstract}

Keywords: $21^{\text {st }}$ century skill, learning media, speaking skill, YouTube

\section{INTRODUCTION}

In most cases, English is considered as a second language or even as a foreign language in some countries, thus it is likely to create such a difficult situation to learn and master the language. As a consequence, the language students are expected to be able to master the four language skills, which are speaking, listening, reading and writing. All skills of the language are actually important to be learned, but speaking is one of the most crucial 


\section{Yuli Nurmala Sari \& Margana}

skills to be mastered since it can be employed as a means to communicate effectively. Speaking can be regarded as an output in learning a language as, instinctively, a language has a function as a means to comunicate. In addition, speaking is a skill which requires the students to not only have an ability in understanding what people are trying to express but also an ability in responding and giving a suitable and effective reply, so that it can be called as a communication. Henceforth, media presence is very important to support the language learning, because learning media has a big role and influence for achievement of desired educational goals.

Social media refers to a rapid technological advancement in which self-development is required to keep abreast of existing developments. Therefore, teachers are required to not only provide a monotonous language learning but also provide a language learning that can foster autonomous and creativity as well as create a learning situation in which the students become more productive in learning the target language in accordance with the demands of $21^{\text {st }}$ century skills where the students are required to have high creativity and innovation, are required to be able to express, analyze and also solve problems, as well as be able to interact and be able to work well with other people. The requirements are what will make students more confident, autonomous in the future and be able to compete domestically and even internationally.

There are several media sosial that can be accessed and employed by people to support the language learning, one of which is YouTube. YouTube is a website which lets on users to watch, upload or share video by online. Generally, a considerable amount of contents can be found in YouTube, such as people talking about their interest, news, education, life, procedure in creating something, and others. Related to education, especially in language, YouTube has a crucial role in affording the information since YouTube can be accessed by the students from all the country around the world where every people have language differences. That is to say, YouTube is considered as a source of material by online that can be employed in the process of language learning activity due to enhance the students' speaking skill.

In learning English, YouTube is likely to contribute a huge amount of advantages in improving the students' ability in English, as mentiones by Bastos \& Ramos (2009) in their research result that asserted that the student are interested in the process of teaching and learning using video, which consists of sound, graphics and animation, which is more interesting than textbooks, worksheets, slides, projectors and films. In addition, it is also stated that students are likely to choose videos available on YouTube with teacher guidance, thus, students can learn more related to vocabulary in order to be able to give opinions and discuss a certain topic which make them more confident in learning languages. In line with another research conducted by Almurashi (2016) in which the research is carried out through online survey for the students who watched short clips on YouTube. The results of the research showed that more than $85 \%$ of participants were agree that YouTube can improve their competencies and understanding in English.

In the other hand, Muna (2011) has been conducting the research using YouTube as learning media in the classroom. The research was conducted for knowing the efectiveness of using YouTube for increasing the speaking skill of the students in Senior High School. 
The use of YouTube as a learning media is effective because students can improve their speaking skills. It can be seen from vocabulary improvement, grammar, pronunciation, and ideas related to the content of the topic. This also can be seen from the results of their tests namely pre-test 37,225 , middle test 67,45 , and post-test 73,40 . In the other hand, the use of YouTube as a learning media also makes the classroom more conducive and students became more focused. Related research was also carried out by Ariyanto (2015), and this study was conducted at Junior High School with the results that using YouTube as learning media is effective with students scores are increase, the pre-test pronunciation showed 2.83, increased in post-test 1 to 3.86 and post-test 2 being 3.89. The pre-test vocabulary showed 2.5 , increased in post-test 1 to 3.6 and post-test 2 being 4.33 . The grammar pre-test showed 2.5 , increased to 3.58 in post test 1 and became 4.22 in post 2 . Then the fluency in the pretest showed a result of 2.83 increasing to 3.41 in post-test 1 and being 3.50 in post test 2 .

From the previous study conducted, it can be concluded that YouTube has a beneficial effect in learning activity, especially in language learning activity. However, even though YouTube is considered an effective language learning media for the students, the prior research primarily only discusses about the implementation of YouTube as a language learning media. In other words, there is no explanation regarding to how to produce a video based on the students' creativity, how to make the students more active in speaking, and also how to produce a video in accordance with the students' own interest to level up their speaking skill as well as improve the students' creativity since the students are required to be more creative and productive in language learning based on the $21^{\text {st }}$ century skill.

Therefore, the rapid development of the media has encouraged the author to explore more about the usefulness of social media in language learning. Since the social media has been developed at this time, especially YouTube, it is considered necessary to use it in the development of language learning along with the implementation of other teaching methods to create a more joyful and challenging language learning activity. In the present study, the author wants to show and present numerous ideas related to the use of social media, especially YouTube, in which the students are expected to not only get information and English exposure from YouTube but also get the chance to improve and produce a learning product so that the implementation of YouTube can be associated with other contents in accordance with student interests.

\section{LEARNING MEDIA FOR SUPPORTING LEARNING ACTIVITY TO INCREASE THE STUDENTS' SPEAKING ABILITY}

\subsection{Speaking between Ability and Activity}

Mastering language is closely related to the speaking ability of the students which affects how they communicate with others. It can be interpreted that master of a language can be seen from how fluent students are in using the language to communicate. According to the New Webster Dictionary (1994: 932) speaking is a delivery of intentions, ideas, feeling, contents and purpose. It can also be referred to as someone's communication with others by using spoken language so that the purpose can be understood by others. It can be said that speaking is oral communication in two ways between speakers and listeners.

Broadly, communication has a dependence on speaking ability. Whereas speaking ability is a person's strength or skill in presenting language to communicate with others 


\section{Yuli Nurmala Sari \& Margana}

orally. That is also affects the success of someone hearing and responding to the meaning of the words in accordance with the expectations that exist so that communication is created. This is in accordance with what is expressed by (Nunan, 1991: 39) that the success of mastery of language can be measured in terms of the ability to have conversations with target language.

Speaking ability is related to the competence of students to respond and do communication to other people. Not only understand what is conveyed by the speaker, but someone have to be able to respond to it. In speaking ability can be marked that a person does not only act as a listener but also able as a respondent or speaker. On the other hand, Scoot and Ytberg (2000: 33) suggest that speaking is an ability that most determines a teacher in teaching a language. It can be interpreted that the way a teacher teaches whether students can improve their abilities in language, especially speaking skills. This also relates to learning activities inside and outside of the classroom.

Talking about activities, this is certainly related to the creativity and integrity of a teacher. Teachers can implement various activities to support learning such as role play, discussion, games, drill or using information gap activities which according to Harmer (1991: 95) can make students practice speaking as in live communication. Besides that, the activity certainly requires a learning media that supports a learning to foster the interest of students to apply it outside or inside the classroom. Therefore, if a learning activity can be done outside the classroom, the possibility of increasing students' abilities in ability speaking can be achieved properly.

\subsection{Learning Media}

The purpose of learning media is to suport the process of teaching and learning. This argument is suported by Azhar Arsyad (2002: 4) where learning media are media that carry instructional messages or contain teaching intentions which stimulates student to learn. On the other hand, Munadi (2013: 7) state that learning media is all about a thing that can deliver or convey a message from the planned source, so that it can provide a conducive environment for efficient and effective in process of teaching and learning. It can be conclude that learning media is a tool for facilitating to convey the messages in process teaching and learning.

In this technology era, learning media is not only limited by books and whiteboards, technological advances are very fast making everything easy and more interesting. It depends on how creative the teacher is in utilizing these opportunities, according to the learning media. Falahudin (2014) states that the roles of the teacher are to provide, show, guide and also to motivate the students, so that they can interact with various existing learning resources. It is not only about resources in the form of people, but also other learning resources. Not only learning resources that are intentionally designed for learning purposes, but also available learning resources. All learning resources that can be found, choosen and used as a learning resource for the students.

Because of that, the kind of learning media in the technological field can be found in all aspect, one of them is can be found on social media. McGraw Hill Dictionary tells that social media is a means used by people to stay connected with each other. They can create, 
share, and exchange the information and idea in virtual community. In the other hand Taprial and Kanwar (2012) state that social media is a tool for being a social people by sharing their photo, video, news about their activity to others. In this way, social media has a deep relationship with communication. Social media as a communication means that reached by anyone and whenever needed. It can be conclude that social media can be utilized as learning media for improving the student's speaking skill since the sosial media as a platform of information and interaction technologies for people to discuss their issues and opinions.

Learning media can be obtained from various forms of social media, such as Facebook, Wikis, YouTube, Blog forums and so on ( $\mathrm{Li}, 2017)$. In the other hand, Batos and Ramos (2009) state that nowadays the trend of use technologies for process learning focuses on the application related web 2.0, it can encourage the students to interact socially, create and share information as well. He also states that YouTube is an application in the form of channels which provides easier access for sharing video from the video that was made. It can be interpreted that YouTube as social media can be an opportunity as a learning media since its give the good benefit and can improve the students ability in learning in the education field subject, especially in language learning.

YouTube is a video repository founded in February 2005 (according to "about" page of YouTube platform). YouTube is not only give the student about information that is needed, but also provide information that the students want to provide such as giving opinions, providing information on knowledge, interests and others. so that the use of YouTube is not only limited to searching for information but also can develop capabilities in creativity. In line with argument by Sesar (2016) that YouTube is one of the social media with a website that provides various kinds of videos ranging from video clips to films, as well as videos made by YouTube users themselves. He also state that now, YouTube is the most popular social media based on sharing video with long duration, where many people use YouTube as a place to work especially for young people.

\subsection{The $21^{\text {st }}$ Century Skill}

Nowadays, education is in the knowledge age with an accelerated increase in extraordinary knowledge since technological changes occur almost every day. Bouzid (2016) argues that nowadays, Students are expected to be able to achieve their success not only in their skills in showing manual skills, moderately, they are expected to be able to demonstrate the ability to search, discover, share, and also use information to solve complex problems. However, in the $21^{\text {st }}$ century the crucial things is not only about developing the knowledge and character but also the students are expected to be able in developing their skills in various domains. It does not mean that knowledge and character are not important. In the field of education in Indonesia, the development of knowledge and character has become a basic process of teaching and learning in the classroom, it begins from basic school until university. According to Zulkarnain (2015), cognitive or knowledge based education models can be seen as the oldest model in the history of education, which means that the development of knowledge has long been applied. He also revealed that character formation must be carried out systematically and continuously involving aspects of "knowledge, feelling, and action". So it can be concluded that the development of knowledge and character has taken place in the world of education, especially in Indonesia. In "action" 
aspect is included in the category of skill development which is of course in achieving quality education and according to the demands of the 21st century, aspects of skill development have to be considered, equal to the development of knowledge and character.

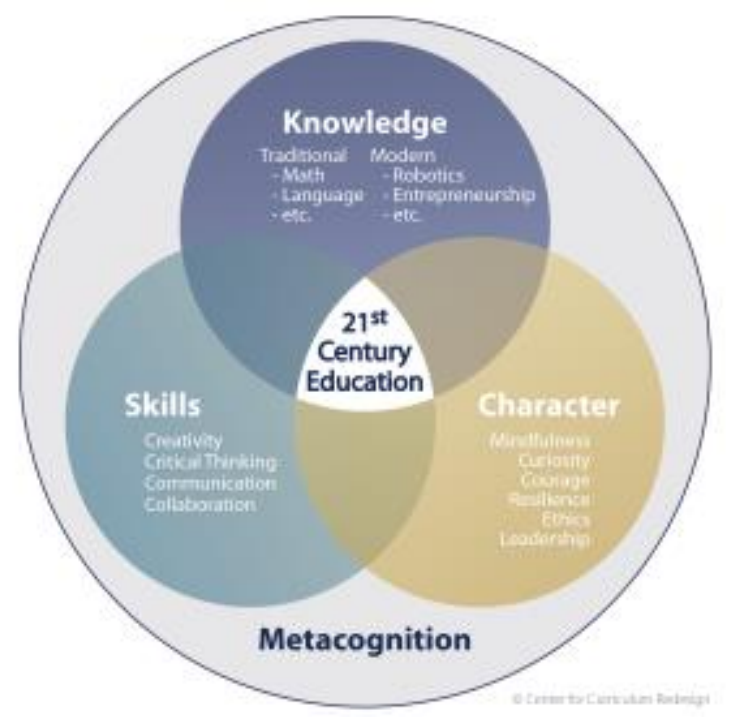

Figure 1. Three dimensions of metacognitif by Bialik and Fadel (2015).

Also in line with the theory of Bialik and Fadel (2015) in $21^{\text {st }}$ century skill, learning plans must follow three dimensions of education: knowledge, character, and skills, that includes in metacognition (look at Figue 1). Metacognitive is the ability to control the domain or cognitive aspects. In $21^{\text {st }}$ century education, there are three dimensions which must be considered, that is knowledge, skills and character. In this area, we are going to focus in skills where skills are believed as teaching skills will detract from teaching knowledge and character. Bialik and Fadel (2015) also state that in skill area, there are four character that are creativity, critical thinking, communication and collaboration. Here, the explanation of four skill's characters.

First, creativity has proven to be an integral part of various skills, including scientific thinking, entrepreneurship, design thinking and others. creativity is an activity that develops knowledge to the real thing or is developed in a work practice. In line with theory of Trilling and Fadel (2009:59), people who have ability in the form to create new things of products or services and make better process to improve world's global economy are qualified in the $21^{\text {st }}$ century. Creative skill has to apply in the field of education. Students are creative when they are able to implement the new ideas or innovations, to think differently, to work creatively with others and to produce a product. It allows students to get a beneficial for facing many problems, to discover problem solving and to face the global competition in the future.

Second, critical thinking, according to The Nasional Council for Excellence in Critical Thinking in Bialik and Fadel (2015: 7) defines that critical thinking is a process of intellectual discipline that skillfully and actively constructs, analyzes, synthesizes, and evaluates information produced by or collected from, investigation, experience, reflexion, 
thought, or interaction, as a mentor to belief and action. Since in this era, everyone has to share any information and knowledge. The student has to able in sorting the information about everthing. In the other hand, critical thinking also the way how the students solving their problems. The learning process is something factual, the students should be able to find out of every problem that they face in their daily life or even in unpredictable condition.

Third, the effective communication is how to convey messages to others clearly and unambiguously with as little mistakes as possible, communication skill is primary important for successful life through activity (Reddy \& Gopi, 2013). Communicative skill is an ability that must be honed, because not all people have ability to talk effectively. In line with theory of Ahmad (2016) that communication skills involve of speaking, listening and understanding systematicly and continously process. Most of people are born with talent to talk, but we still have to learn speak well to communicate effectively.

Fourt, collaboration can be defined as involvement between students in coordinated efforts to solve common problems, complete the tasks, or create the products together. According to Lai (2011: 2) collaboration can be interpreted as reciprocal engagement of entrants in a coordinated efford to solve the problems together. He also said that Collaborative interaction is distinguished by sharing a goal, equality of the structures, and high level of negotiations, interactivity, and mutuality. Interaction that produces explanation in detail will be very helpful for improving the students ability in process teaching and learning. Collaboration also have a powerful effect, especially for low achieving students. Collaboration also can be interpreted as a model learning in $21^{\text {st }}$ century in process of teaching and learning, where the students are expected to think critically in responding to developing issues.

\section{WHY YOUTUBE IS BELIEVED FOR IMPROVING THE SPEAKING ABILITY OF THE STUDENTS?}

\subsection{Supporting Students to Practice Autonomously}

Learning English, especially to improve the speaking skill, is considered important to get more attention since it is likely for the students to have problems producing speech in communicating to each other. This is in accordance with the result of research carried by Megawati (2016) in which it reveals that speaking skill gains the first position in causing the students to face any difficulties in their English mastery due to the less of vocabulary, problems in memorize, problems in utterance, fear of making mistake, laughed at by friends, and less of knowledge of grammar and English reinforcement. Also, a research conducted by Afisa and Yolanda (2015) in Megawati (2016) stated that the frequency of practice to speak English along with other psychological factor are being a reason why the students are difficult to master speaking ability.

Due to the fact that speaking skill is a productive skill, it is considered necessary to have a lot of time in practicing to communicate with the target language. However, in reality, the time possessed in class learning has limitations so that a breakthrough in learning is needed concerning student to be autonomous. The autonomous of students here means that students can carry out self-development outside the classroom which certainly also requires students in developing critical thinking, creativity, communicative and also working with 
their friends and certainly that can be monitored by the teacher within the process of language learning.

In relation to the autonomous learning, technology can be relied upon as a media, where currently internet-based technology is in great demand by the wider community, especially teenagers, so that the use of technology is not regarded as an uncommon thing to them. The results of UNICEF's research together with UN agencies and partners including the Ministry of Communication and information and Harvard University (Panji, 2014) revealed that online activities of children and adolescents involving 400 respondents between the age of 10 to 19 years representing the urban and rural areas throughout Indonesia was about $98 \%$ of children and adolescents in which $79.5 \%$ of them were internet users. Therefore, in other words, this enables the utilize of technology in classroom and autonomous learning to be carried out and have maximal function for the students to practice in the classroom.

\subsection{Appropriate Learning Media in 21st Century}

In this study, it is also revealed that there were three motivations for children and adolescents to access the internet, namely to find information, to connect with friends and for entertainment. Information can be obtained from various social media, one of which is YouTube, where YouTube itself has a more interesting visual motion, lots of information obtained, it can be used in the form of live, and other benefits. It can also support the students in facing the $21^{\text {st }}$ century skills, where the students are required to have skills in innovation in unlimited creativity. In accordance with what was told by Soh, Arsad, \& Osman, (2010), in the $21^{\text {st }}$ century, students are expected to have more and better skills to face a better future. Furthermore, the students are also expected being able to apply the knowledge they have and learn to face the challenges in real life. Only mastering a basic skill are not enough to face the world. In addition, the definition of achievement has to extended covering the $21^{\text {st }}$ century skills.

Generally, in the previous studies, the reseachers are utilizing YouTube as a learning media to obtain information. Henceforth, in this paper, the author provides a description of the strategy in using YouTube not only as a search information, but also as a tool for the students, autonomously or in groups, to improve their ability in expressing opinions, sharing information and also to level up their communication skill especially in English related the demands of $21^{\text {st }}$ century skills along with the utilize of technology. In $21^{\text {st }}$ century skills, there are four educational characters that are encouraged for the students' achievement, namely creativity, critical thinking, communication and collaboration where quality is preferred.

YouTube as a learning media in the character area that exists in $21^{\text {st }}$ century skills can be seen by having the aim of improving the English communication of student. The development of YouTube as a learning media which is expected to be not only as a source of information but also as a source to produce an effective product of the students while, at the same time, improving their communication skills. It is very possible to be carried out because currently the use of YouTube is very familiar and can be used as a personal account in ease. There is a lot of advantages of YouTube as the delivery of interests such as the 
delivery of opinions related to the latest issues, information on daily life, make up information, and other interests as well.

The utilization of YouTube as an effort to develop the students' communication can be done in accordance with the $21^{\text {st }}$ century skills. First, the students can explore their creativity in planning to build a topic to be discussed in their products in which it can be any discussions based on their interests and talents to frame as attractive as possible of the discussion topic that will be done. For example, discussions related to existing issues such as their opinions regarding flat earth and round earth, or other topics such as those conducted by Nessie Judge, a YouTube influencer who has more than one million subscribers. She often expresses opinions or reactions related to a current and up to date topic, in fact, she also provides tips related to the existing discussion. Second, students are required to show critical thinking in discussing topics that will be created based on experience by analyzing and observing the topic of discussion. In this case, the students need to involve new ways of thinking outside their previous habits. For example, to create a YouTube video related to the topic of flat earth, it is considered necessary for them to look for and analyze things related to the flat earth in order to strengthen their opinions regarding the topic. Third, students are required to understand the arrangement in creating a good and effective communication that can be acceptable to the listener and in accordance with the existing discussion. Since the main objective is to improve the students' speaking skill, thus the utilize of vocabulary, grammar and sentence structure must be in accordance with the rules of English and can certainly respond to existing discussions. Fourth, in this realm, students are expected to work together with their friends in finding ideas, developing ideas, as well as analyzing and observing the ideas that are going to be carried out. Students can share their own assignments and be responsible for their respective tasks, assignments given in school and outside of school. This is in accordance with the opinion of Zubaidah (2017) that collaboration can be developed through experiences in schools, between schools, and outside of school where students can collaborate collaboratively on authentic projects or develop their skills through deep peer tutoring learning group. It can be interpreted that each student has advantages and disadvantages in working together with their peers since they can fill each other's shortcomings.

\subsection{Many Benefits can be Obtained}

Hence, the use of YouTube can be done optimally, where the process of producing a product can also hone the demands of the $21^{\text {st }}$ century with the aim of developing their communication towards a better and more productive activities. In this case, the teacher can provide feedback on the students' products with a focus on developing their communication ability in English. If learning as this task can be done, many benefits can be gained. Firstly, lack of time in learning is no longer a reason and problem in development of the students' language skill, especially the speaking skill of students. Secondly, students can develop their creativity, sharpen their critical thinking, and mutual cooperation in solving problems in which, in this case, not only to create products as the output of the language learning but also consider the process as a critical and crucial thing within the language learning. Thirdly, it can provide a learning situation in which the interests and talents of students can be explored and displayed within the process of language learning. Fourth, the benefit that can be taken 
that is students are likely to have the experience in collaborating and communicating with other people to face the world of work in the future by using technology and social media skills that also enable them to collaborate and communicate with international groups, in line with the theory put forward by Carr \& Hayes (2014) stated that social media is a media based on internet that enable users to have the opportunity to interact and present themselves, both instantaneously and deferred, with a wide audience and drives the value of user-generated content and perceptions of interaction with the others.

\section{CONCLUSION}

At the present moment, YouTube is considered as an interesting learning media since it is suitable with the demands of the $21^{\text {st }}$ century skills. Learning media are not only those which can provide information or theory about subject learning but also can be used for practice in order to level up the students' abilities in speaking. That is to say, YouTube is regarded as a critical learning media in order to aid the students for improving their speaking skill. In addition, YouTube can also be employed in language learning to increase the students' autonomous in learning as well as provide students with a better, interesting, easily accessible learning experience that can still be monitored by the teacher. The practical language learning using YouTube is also likely to assist the students in adapting to the technology development and global competition within the international environment. By having a specific creativity, critical thinking, a good and effective strategy of communicating and being able to collaborate with other people, the students are expected being able to face the kind of an assignment in real life later by having good quality of course. Furthermore, the most prominent thing in the use of YouTube as a learning media is, it can improve students' speaking abilities, where the problems of time will not be a reason for thes students to practice English in order to achieve learning goals.

\section{REFERENCES}

Ahmad, S. R. (2016). Importance of English Communication Skills. International Journal of Applied Research 2(3), 478-480.

Almurashi, W. A. (2016). The Effective Use Of YouTube Videos For Teaching English Language In Classrooms As Supplementary Material At Taibah University In Alula. International Journal of English Language and Linguistics Research 4(3), 32-47.

Ariyanto, Novie. (2015). Improving Students' Speaking Skill by Using YouTube Video (A Classroom Action Research at the Seventh Grade Students of SMP N 15 Surakarta in the Academic Year 2012/2013). Surakarta, Indonesia. Retrieved from Sebelas Maret University database.

Arsyad, Azhar. (2002). Media pembelajaran. Jakarta, Indonesia: Grafindo persada.

Bastos. A. \& Ramos. A. (2009). YouTube For Learning English as a Foreign Language: Critical Thinking, Communicative Skills (p. 2087-2092). Proceedings of EDULEARN09 Conference Paper on Universidade do Minho, Barcelona, Spain.

Bialik, M. \& Fadel, C. (2015). Skills for the $21^{\text {st }}$ Century: What Should students Learn?. Massachusetts: Center for Curriculum Redesign. 
YouTube as a Learning Media to Improve the Student's Speaking

Bouzid, H. A. (2016). Boosting 21th Century Skills through Moroccan ELT Textbooks. Journal of English Language Teaching and Linguistics 1(2), 109-144.

Carr, T. C. \& Hayes, R. A. (2015). Social Media: Defining, Developing and Divining. Atlantic Journal of Communication 23(1), 46-65.

Falahudin, Iwan. (2014). Pemanfaatan Media dalam Pembelajaran. Lingkar Widyaiswara Journal 1(4), 104-117.

Harmer, Jeremy. (1991). The Practice of English Language Teaching. New York: Longman

Lai, E. R. (2011, June). Collaboration: A Literature Review. Retrieved from Pearson.

Li, Voyce. (2017). Social Media in English Language Teaching and Learning. International Journal of Learning and Teaching 3(2), 148.

Megawati, Fika. (2016). Kesulitan Mahasiswa Dalam Mencapai Pembelajaran Bahasa Inggris Secara Efektif. JURNAL PEDAGOGIA 5(2), 147-156.

Muna, MS. (2011). Utilizing YouTube Videos to Enhance Students' Speaking Skill. Surakarta, Indonesia. Retrieved from Sebelas Maret University database.

Munadi, Yudhi. (2013). Media Pembelajaran (sebuah pendekatan baru). Jakarta, Indonesia: Gang persada (GP) Press.

Nunan, David. (1991). Language Teaching Methodology. A Textbook for Teachers. London: Prentice Hall

Panji, Aditya. (2014). Hasil Survey Pemakaian Internet Remaja Indonesia. Retrieved Desember 12th, 2018 from https://tekno.kompas.com/read/2014/02/19/1623250/Hasil.Survei.Pemakaian.Internet.Re maja.Indonesia.

Reddy, B. B. \& Gopi, M.M. (2013). The Role of English Language Teacher in Developing Communication Skills among the Students of Engineering and Technology. International Journal of Humanities and Social Science Invention 2(4), 29-31.

Scott, W.A., \& Ytreberg, L.H. (1990). Teaching English to children. New Work: Longman.

Sesar, A. D. (2016). Media Sosial YouTube. Retrieved December 11th, 2018 from https://www.kompasiana.com/sesarrrrr/584a24c506b0bd7a0732fdf7/media-sosialYouTube.

Soh, T. M. Tuan., Arsad, N. M. \& Osman, K. (2010). The Relationship of 21st Century Skills on Students' Attitude and Perception towards Physics. Procedia Social and Behavioral Sciences 7(C), 546-554. Proceedings of International Conference on Learner Diversity, Faculty of Education, Selangor, Malaysia.

Taprial, V. \& Kanwar, P. (2012). Understanding Social Media. London: Ventus Publishing ApS.

Trilling, B. and Fadel, C. (2009). 21st Century skills: learning for life in our times. New York: Jossey - Bass.

Zubaidah, Siti. (2016). Keterampilan Abad Ke-21: Keterampilan yang Diajarkan Melalui Pembelajaran. Proceedings of the National Education Conference, Faculty of Mathematics and Natural Sciences, South Borneo, Indonesia.

Zulkarnain. (2015). Pendidikan Kognitif Berbasis Karakter. Tasâmuh Journal 12(2), 189203. 